\title{
東北地方太平洋沖地震における宮城県仙台市の 水道管路被害状況の分析
}

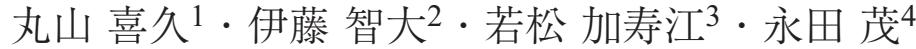 \\ 1正会員 千葉大学准教授 大学院工学研究科（干263-8522 千葉市稲毛区弥生町 1-33） \\ E-mail: ymaruyam@tu.chiba-u.ac.jp \\ 2元 千葉大学 工学部都市環境システム学科（†263-8522 千葉市稲毛区弥生町 1-33） \\ 3 正会員 関東学院大学教授 理工学部土木学系（干236-8501 横浜市金沢区六浦東 1-50-1) \\ E-mail: wakamatu@kanto-gakuin.ac.jp \\ 4正会員 鹿島技術研究所 都市防災・風環境グループ（†182-0036 東京都調布市飛田給 2-19-1） \\ E-mail: nagata-shigeru@kajima.com
}

2011 年 3 月に発生した東北地方太平洋沖地震では, 都市ガスや上下水道などの地中埋設管に多数の被害 が生じた。 とくに宮城県仙台市では約 23 万戸の断水が発生し, 水道管被害の多くは丘陵地を造成した人工 改変地に集中した。管路被害予測式では, 地震動強さの関数である標準被害率曲線に各種の補正係数を乗 じることにより, 被害率を算出している。しかしながら, 自治体の地震被害想定等では, 改変地形の考慮が 必ずしも充分ではないことがある。本研究では，東日本大震災により被害を受けた宮城県仙台市を対象地 として水道管被害の分析を行い，丘陵の造成地の影響を考慮する方法を提案する。なお，補正係数の值に 関しては，他地域の事例も併せて分析したうえで設定すべきものと考えられる.

Key Words: The 2011 off the Pacific coast of Tohoku Earthquake, water distribution pipeline, developed hilly area, damage ratio

\section{1.はじめに}

2011 年 3 月に発生した東北地方太平洋沖地震で は，東日本の広範囲にわたって電力，上下水道，都市 ガス，通信などのライフライン施設に被害が生じた。 Nojima ${ }^{1)}$ は, これらのライフラインが途絶した需要 家数および復旧日数を 1995 年兵庫県南部地震の際 と比較しており, 東北地方太平洋沖地震直後に電力 や上水道が途絶した需要家数は兵庫県南部地震の場 合よりも多いが，その復旧状況は津波による被災地 域を除けば両者にあまり大きな差がないことを示し ている.ライフラインが途絶した需要家数に差があ るのは，両地震のマグニチュードが大きく異なるた め, 強震動に曝された地域が東北地方太平洋沖地震 の方が広範であったことが影響しているものと考え られる。

一方で，ライフラインが途絶した需要家数に差が あるにもかかわらず，両地震で復旧日数にあまり差 が見られなかった理由としては, 兵庫県南部地震を 契機とした地震対策が功を奏したことが挙げられ
る。例えば，都市ガスに関しては，兵庫県南部地震， 2004 年新潟県中越地震, 2007 年新潟県中越沖地震と 比べて，本支管の被害率は低く，復旧に要した期間 も兵庫県南部地震の際よりも明らかに短かった2）。 これは，耐震性の高いポリエチレン管 (PE 管) の敷 設割合を兵庫県南部地震以降高めてきたことや即時 の供給停止を実現するブロック化を進めてきたこと などが一因とされている2）。

このことを踏まえると, 大地震後にライフライン 施設の被害状況を継続的に分析することは，過去の 地震を受けて講じた対策の事後評価や次の地震によ る被害予測を行う際の基礎資料として有用と考えら れる。東北地方太平洋沖地震では, 宮城県内を中心 にピーク時で約 220 万戸以上が断水しだ）、鍬田・ 片桐 ${ }^{4)}$ による 187 市町村で断水が発生したものの 兵庫県南部地震の際の神戸市での配水管被害率と比 べて全体的に軽微であったことが報告されており， この地震の際の詳細な水道管の被害は分析する意義 がある。

そこで, 宮城県仙台市の上水道管路データと導水・ 
表-1 仙台市水道局に扮ける導水・送水・配水管の被害数 と延長

\begin{tabular}{|c|r|r|r|r|r|}
\hline 管種 & 管体破損継手抜け & その他 & 合計 & 延長 $(\mathrm{km})$ \\
\hline DIP $^{*}$ & 27 & 84 & 6 & 117 & 2723.1 \\
\hline $\mathrm{VP}$ & 244 & 45 & 8 & 297 & 1514.5 \\
\hline $\mathrm{GP}$ & 4 & 1 & 1 & 6 & 4.9 \\
\hline $\mathrm{SP}$ & 1 & 4 & 7 & 12 & 137.3 \\
\hline $\mathrm{LP}$ & 1 & 1 & 0 & 2 & 3.4 \\
\hline PP & 2 & 0 & 1 & 3 & 52.7 \\
\hline 合計 & 279 & 135 & 23 & 437 & $4458.0^{* *}$ \\
\hline
\end{tabular}

）耐震管（約 $845 \mathrm{~km} ）$ は被害なし

**) 仙台市内の総延長

送水・配水管の被害データ ${ }^{5)}$ をいて, 地震動強さと 管路被害率の関係を評価する。永田らは，仙台市の 上水道管路の被害状況を定量的に分析し, 宅地造成 地での被害の特徵や管路耐震化の効果を明らかにし ている ${ }^{6)}$. 本研究では, 永田らの結果 ${ }^{6)}$ を踏まえて, 水道管路被害予測式7)-11) と仙台市の管路被害率の比 較を行い，丘陵の造成地で被害が集中することを考 慮する方法を提案する。 さらに, 水道技術研究セン ターが東北地方太平洋沖地震後に見直した管路被害 予測式 ${ }^{11)}$ と比較し，管種，管径，地形に関する補正 係数の妥当性を評価し, 今後の水道管路の地震被害 予測や管路更新計画の立案に貢献できることを目指 す.

\section{2. 宮城県仙台市の上水道管路の被害状況}

2011 年度時点での仙台市水道局の給水人口は $1,028,015$ 人，給水戸数は 468,910 戸である。これ らの需要家に対して，5箇所のダムと宮城県仙南，仙 塩広域水道加の浄水を受水し，4箇所の主要浄水 場，65箇所の配水施設を通じて上水を供給してい る $^{12)}$. 東北地方太平洋沖地震では, 約 23 万戸の断 水，断水人口約 50 万人（断水率約 $50 \%$ ）の被害が発 生し，津波による被害が甚大な地域を除けば 3 月 29 日に全面復旧に至った ${ }^{5)}$ 。水道管路および付属設備 の被害数は 1,064 件であり, 導水・送水・配水管につ いては 437 件の被害があった。管路延長は約 4, 458 $\mathrm{km}$ で, 全体の被害率は約 0.1 件/ $\mathrm{km}$ である ${ }^{5)}$ 。なお,

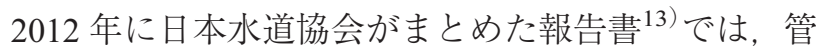
径 $75 \mathrm{~mm}$ 以上の被害状況がまとめられており, 導 水・送水・配水管の被害数は 276 件，被害率は 0.07 件 $/ \mathrm{km}$ とされている.

本研究では, 仙台市水道局から提供を受けた 437
件の導水・送水・配水管被害およびマッピングシス テムによる管路敷設状況に関する GIS データを用い て分析を行う。管種，管径ごとの被害の詳細につい ては，文献5)の通りであるが，表-1に主な管種ごと の被害形態別の被害数を示す。ここで，DIPはダク タイル鋳鉄管，VP は塩化ビニル管， GP は亜鉛メッ キ鋼管，SP は鋼管，LP は鉛管，PP はポリエチレン 管を表す。 437 件の被害のうち，約 70\%の 297 件が VP, 約 $25 \%$ の 117 件が DIP で発生している。なお, DIP のうち耐震継手 ${ }^{14}$ ) 有する管路（延長約 845 $\mathrm{km}^{5)}$ ) では被害がなかった。

図-1に仙台市に打ける導水・送水・配水管の被害 位置と管路の敷設状況を示す。また，図中では，若 松・松岡による微地形区分 (世界測地系) ${ }^{15)}$ も示し ている．赤色（太線）で示した管路がDIPのうち耐 震継手を有するものであり, 被害率（件 $/ \mathrm{km}$ )を算出 する際の管路延長からは除外して考えることとす る。図-2に，微地形区分㧍よび後述する地形補正係 数 $\left(C_{g}\right)$ ごとの導水・送水・配水管の被害数, 管路延 長と被害率を示す。ここで, 被害率は管路延長が充 分長い DIP (一般継手) とVP について管種別に示し, さらに耐震管を除外した全管種の被害率を参考とし て示す

水道技術研究センターは, 管路更新計画の優先順 位付けや地震被害予測に貢献することを目的とし $\tau$, 兵庫県南部地震, 新潟県中越地震, 能登半島地 震，新潟県中越沖地震における管路被害デー夕を用 いて水道管の被害予測式を 2011 年 3 月に提案し た ${ }^{16)}$ 。さらに, 東北地方太平洋沖地震により生じた 管路被害を新たな知見として取り入れて，2013 年 3 月に被害予測式を修正した ${ }^{11)}$ 。提案された被害予測 式は式（1）のようである.

$$
R_{m}(v)=C_{p} C_{d} C_{g} R(v)
$$

ここで, $R_{m}(v)$ は水道管路の被害率 $($ 件 $/ \mathrm{km}), C_{p}$ は 管種・継手別の補正係数, $C_{d}$ は管径別の補正係数, $C_{g}$ は地形別の補正係数で微地形区分に対応付くように 設定されている ${ }^{11), 16)}$ 。また， $R(v)$ は標準被害率で あり最大速度 $(\mathrm{PGV}) v(\mathrm{~cm} / \mathrm{s})$ の関数として以下の

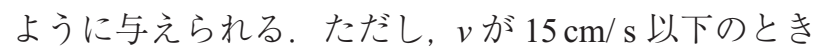
は $R(v)$ が 0 , 適用可能な最大速度の上限は $120 \mathrm{~cm} / \mathrm{s}$ とされている。

$$
R(v)=9.92 \times 10^{-3} \times(v-15)^{1.14}
$$

東北地方太平洋沖地震の際の宮城県仙台市では, 丘陵に敷設された水道管で被害が多数発生している ことが分かる。とくにVP は，約 300 件の被害が発 


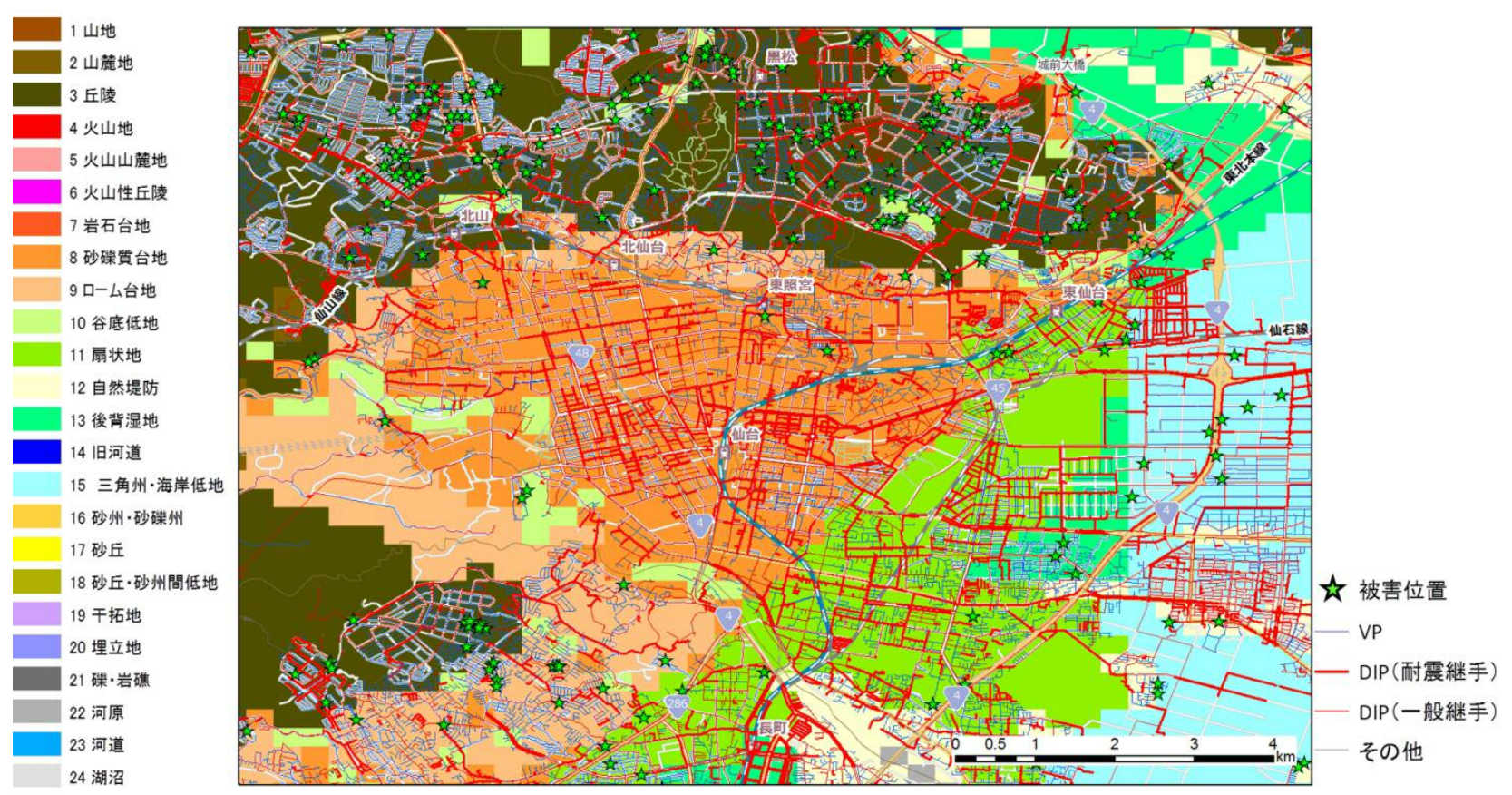

図-1 仙台市中心部における微地形区分 ${ }^{15)}$ および導水・送水・配水管の被害位置と管路の敷設状況

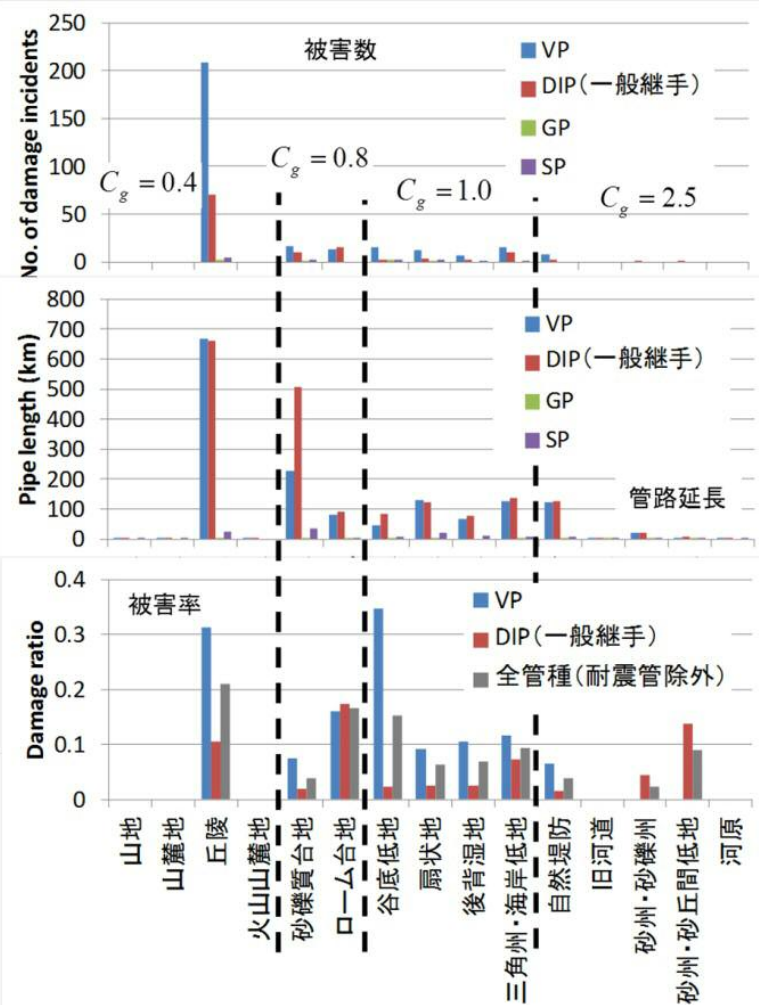

図-2 微地形区分ごとの導水・送水・配水管の被害数と被 害率

生した。丘陵の補正係数 $\left(C_{g}\right)$ は 0.4 と定められて おり，相対的には被害が生じにくい地形と考えられ ているが，仙台市に関してはVP が約 0.3 件/ $\mathrm{km}$, DIP (一般継手) が約 0.1 件/ $\mathrm{km}$ の被害率を示した (図 -2). 式（1）の地形補正係数 $C_{g}$ と仙台市に扔ける被 害率を比較するために，管径補正係数 $C_{d}$ が 1.0 であ

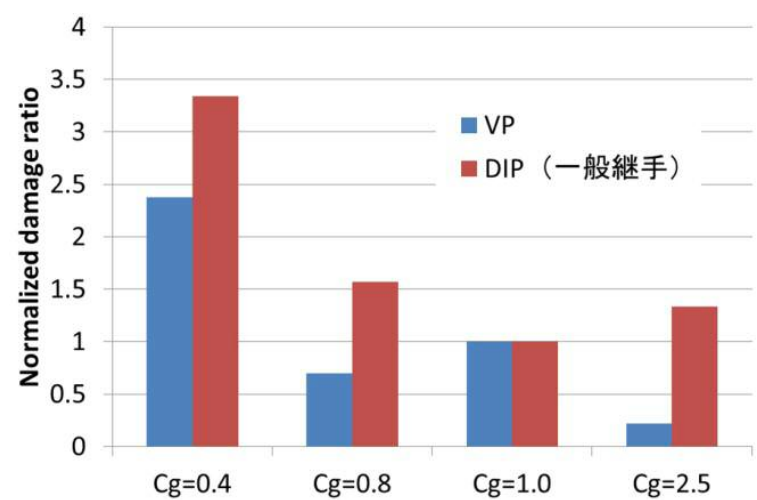

図-3 地形補正係数ごとの被害率 $\left(C_{g}=1.0\right.$ の被害率で基 準化，管径 $100-150 \mathrm{~mm}$ のみ)

る $100-150 \mathrm{~mm}$ の導水・送水・配水管の被害数と延長 を集計し，地形補正係数の值ごとに被害率を算出す ると図-3のようになる。なお，図中では， $C_{g}$ が 1.0 と定められている低地 (谷底低地, 扇状地, 後背湿地 など）の被害率で基準化している，仙台市では，丘 陵で被害が多数生じていることが影響し， $C_{g}$ が 0.4 と定められている山麓地, 丘陵地などで $C_{g}$ が 1.0 の 低地よりも VP が約 2 倍以上, DIP が約 3 倍以上高 い被害率を示しており, 地形補正係数 0.4 との乘離 が大きい. また， $C_{g}$ が 2.5 と定められている自然堤 防, 旧河道, 砂州・砂磼州などの VP の被害率は小さ く, DIPは $C_{g}$ が 1.0 の低地とほぼ同じ被害率を示し ている。これらの地形は沿岸部に多くあることか ら, 津波による被害が甚大な地域の水道管被害が充 分に精查されていないことが影響している可能性も あるため, 詳細な議論は難しい. $C_{g}$ が 0.8 と定めら れている台地（砂礫質台地, ローム台地）に関して 


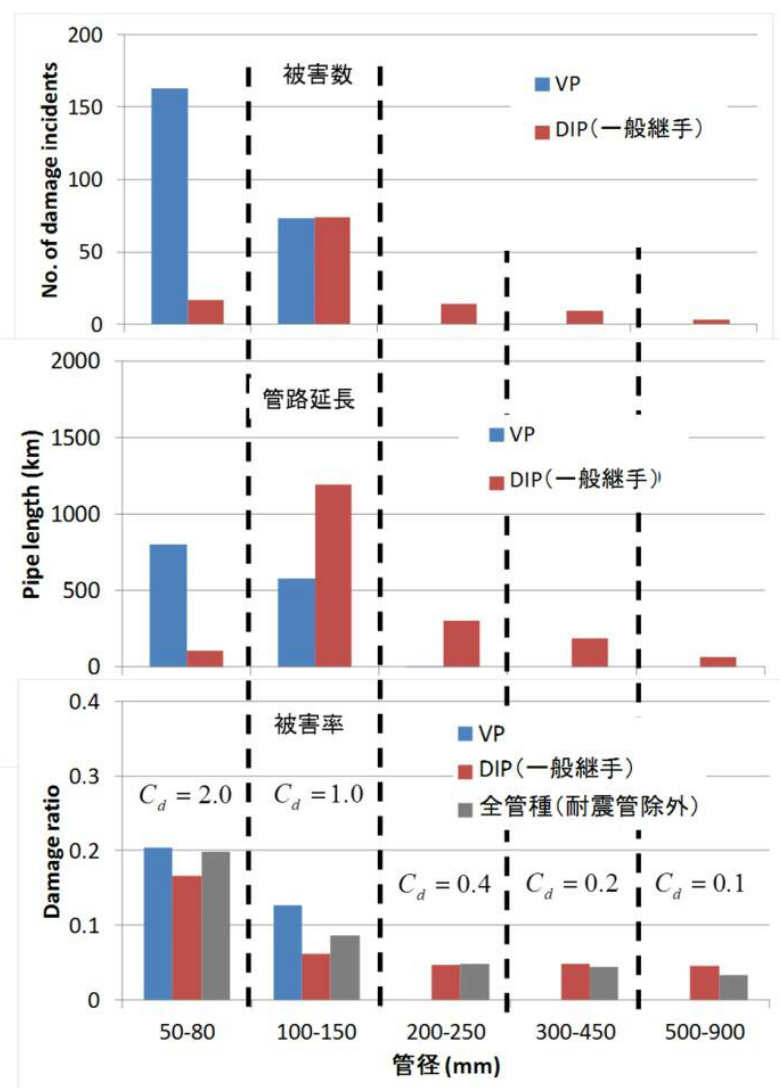

図-4 管径別の導水 - 送水 ·配水管の被害数と被害率

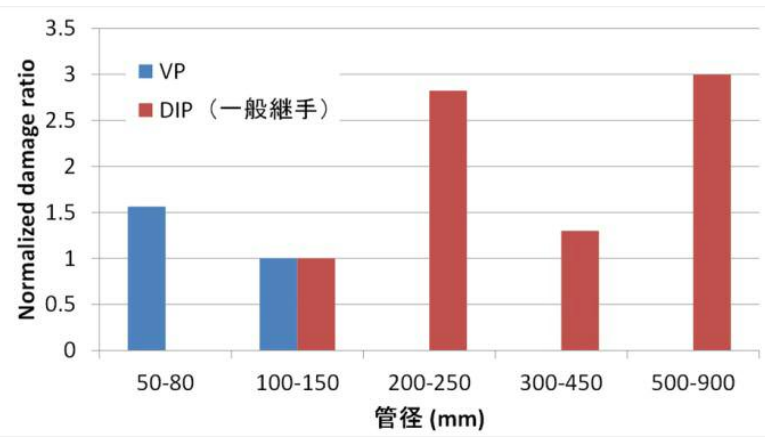

図-5 管径補正係数ごとの被害率（管径 100-150 mm の被 害率で基準化, $C_{g}=1.0$ の地形の被害のみ)

は, VPは概ね補正係数の值と調和的, DIP は低地の 被害率の約 1.5 倍高い被害率を示した。

仙台市全域に関して, 管径別の導水・送水・配水管 の被害に関する分析を行う。図-4には，管径別の被 害数, 管路延長と被害率を示す、VPの被害が管径 $200 \mathrm{~mm}$ 以上で 0 件なのは，管径 $200 \mathrm{~mm}$ 以上の VP が敷設されていないためである。なお，図中には式 （1）で定められている管径に関する補正係数 ${ }^{11)}$ も示 している。図-5は, 式 (1) の管径補正係数 $C_{d}$ と比較 するため, 地形補正係数 $C_{g}$ が 1.0 の低地における被 害数と延長をもとに被害率を算出し, $C_{d}$ が 1.0 であ る管径 100-150 mm の被害率で基準化した結果を示 す。管径 100-150 mm の補正係数が 1.0 , 管径 50-80 $\mathrm{mm}$ の補正係数が 2.0 と定められているが, VP の被
土木学会論文集A1 (構造·地震工学), Vol. 70, No. 3, 377-388, 2014.

害率は管径 50-80 mm のときに管径 100-150 mm に 対して約 1.5 倍高い．管径が大きいほど補正係数は 小さく設定されているが, DIP の被害率は管径 100-150 mm のものと比べて概して高い. 図-4に示 したように仙台市の場合は，管径の大きな DIP の管 路延長は 100-150 mm の延長と比較してかなり短い ため,この結果のみで管径が大きい場合の補正係数 を議論することはやや難しいと思われる。一方で, 仙台市では, 管径 $500 \mathrm{~mm}$ 以上の大口径の DIPに 3 件の被害が生じているため, これらの被害に関して はとくに詳細な検討を要するものと考えられる。

片山ら ${ }^{17)}$ は, 1978 年宮城県沖地震に打ける宮城県 の上水道施設の分析を行っている，仙台市および泉 市（現在は仙台市泉区）に関する分析結果によると， 丘陵部の宅地造成地に被害が集中したことが分かっ ている。本章の結果や東北地方太平洋沖地震の際の 都市ガス施設の被害状況 ${ }^{2}$ を鑑みると, 地形別の補 正係数が小さく設定される丘陵で多くの被害が生じ たことが仙台市の埋設管被害の特徵の一つと考えら れる。

\section{3. 丘陵の造成地の抽出方法に関する検討}

（株）復建技術コンサルタントは，仙台市の造成 宅地地盤図 ${ }^{18)}$ (以下, 造成宅地地盤図とする) を公 開して扮り, 東北地方太平洋沖地震後には造成宅地 の被害分析 $\left.{ }^{19)}, 20\right) や$, 木造建物, 上水道被害と切盛厚

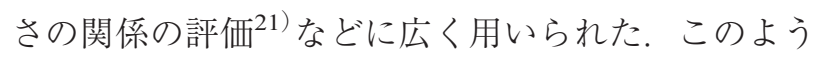
な造成地の位置と規模を把握する手法として, 人工 改変地形デー夕抽出のための手順書 ${ }^{22}$ が国土地理院 によってまとめられている。盛土造成地の位置と規 模を把握するには, レーザー計測による標高データ, 米軍の空中写真, 旧版地形図などが必要である。仙 台市の造成宅地地盤図では, 造成前の地形データを 昭和 30, 40 年代の地形図の等高線から取得してい $3^{23)}$.

詳細な造成地盤図を作成するには多大な労力を要 するが，本研究では全国を均質に網羅したデー夕 セットを用いてマクロに丘陵上の造成地を抽出する 方法について検討を行う。このようなマクロな手法 を検討する目的は, 首都圈での M7 クラスの地震の 切迫性が指摘 ${ }^{24)}$ されていたり, 南海トラフを震源と する巨大地震の発生が懸念 ${ }^{25)}$ されていたりすること を踏まえて, 将来的には広域のライフライン被害予 測への適用を図るためである。本研究では, 微地形 区分 ${ }^{15)}$ と国土数值情報の土地利用細分メッシュデー 夕26）使用する。微地形区分では, 開発前の原地形 


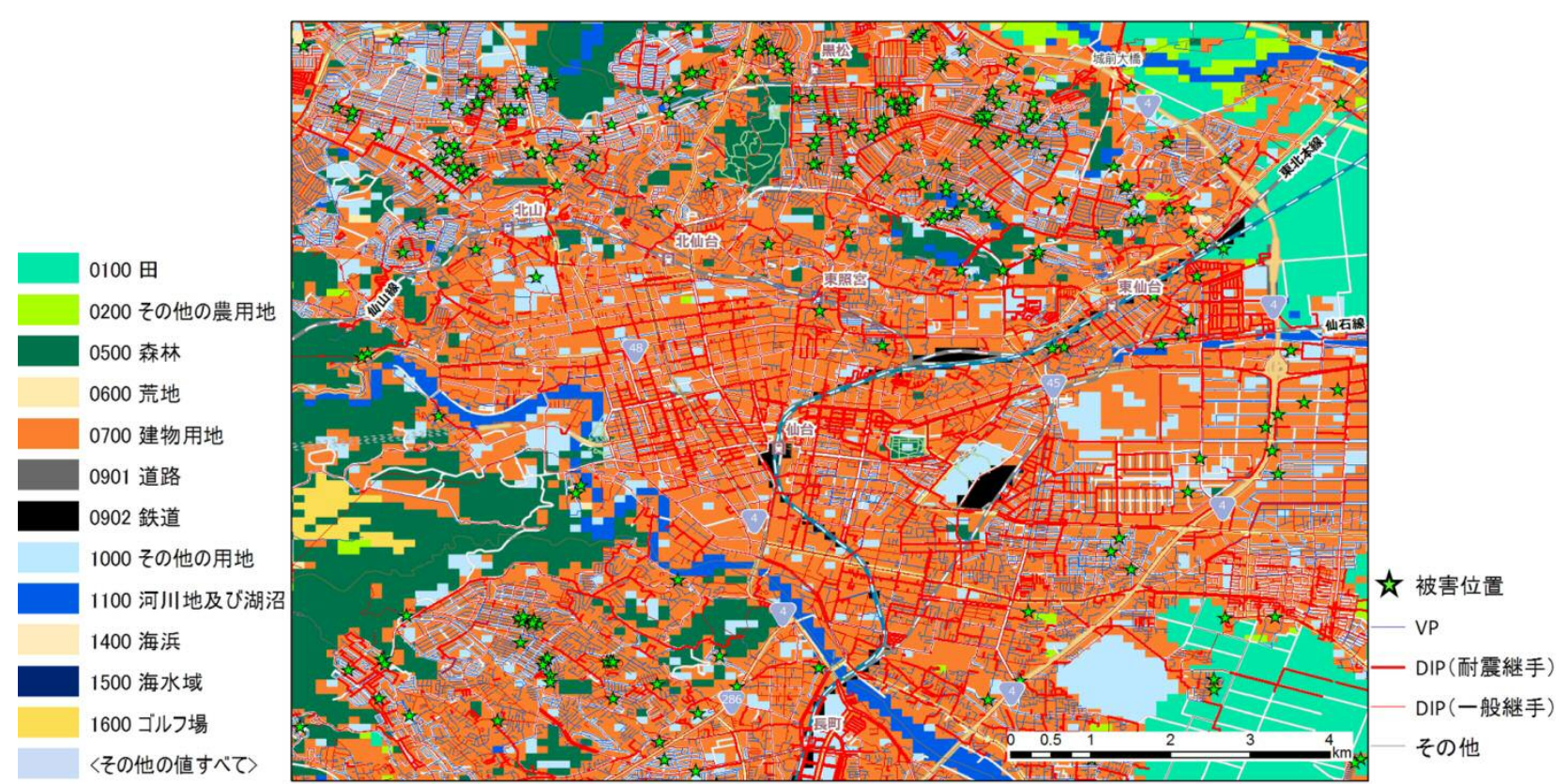

図-6 土地利用細分メッシュデータ（平成 21 年度版）と水道管の被害位置および管路敷設状況（図-1 と同範囲）

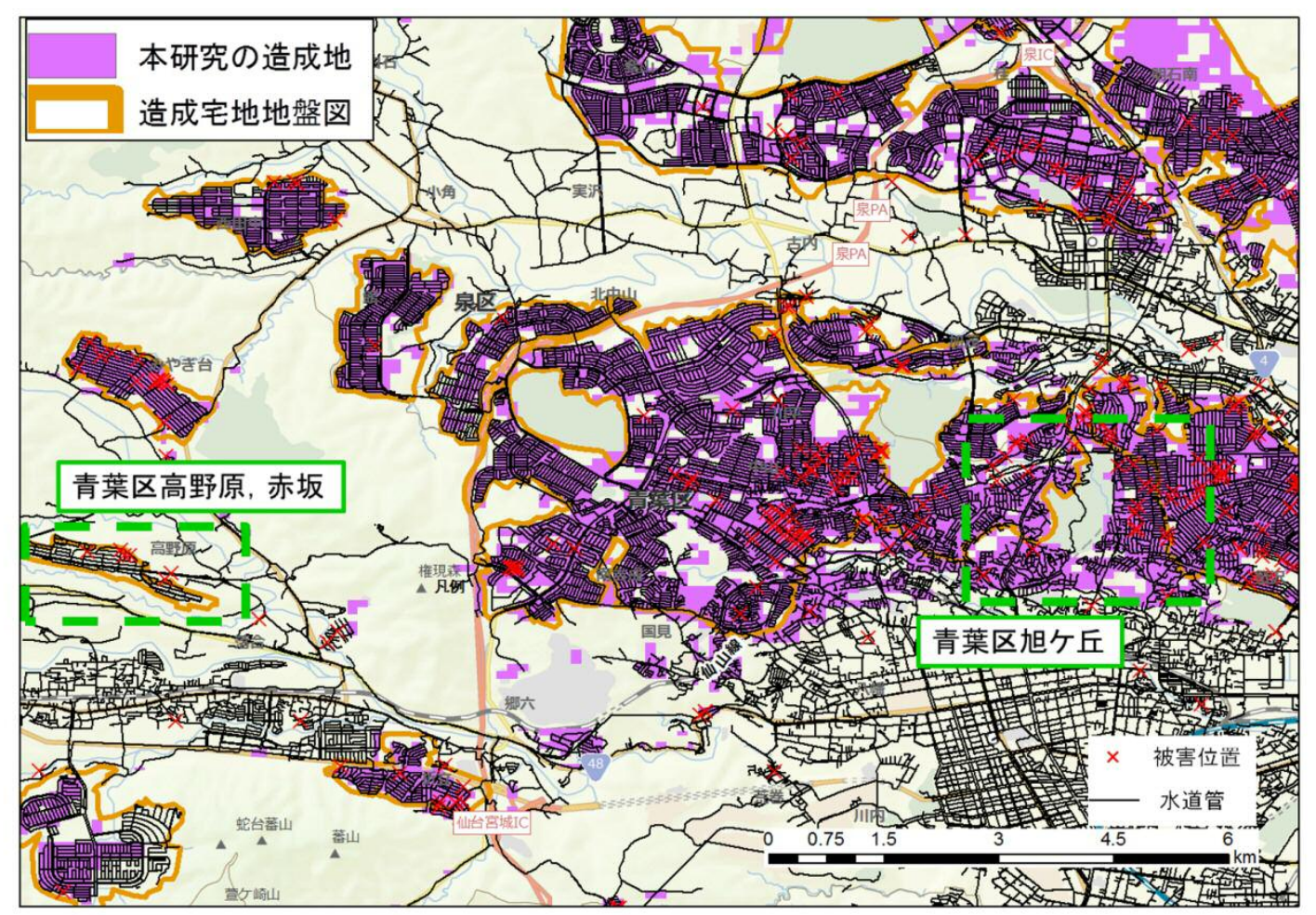

図-7 本研究で推定した丘陵上の造成地と造成宅地地盤図 ${ }^{18)}$ の比較

が $250 \mathrm{~m} メ ッ シ ュ$ 単位で把握できる ${ }^{15)}$ 。土地利用細 分メッシュデータ (平成 21 年度版) は, 人工衛星画 像，1/25000 地形図を用いて整備されたデー夕で, $100 \mathrm{~m} メ ッ シ ュ$ 単位で土地利用の状況が分かる（図 $-6)$.

本研究では, 丘陵の造成地を把握するため, 微地 形区分で丘陵かつ土地利用細分メッシュデータで建 物用途と分類されている地域を抽出することとし
た。微地形区分での丘陵は, 標高が比較的小さく, $1 \mathrm{~km}$ メッシュにおける起伏量が概ね $200 \mathrm{~m}$ 以下の斜 面からなる土地と定義されている27). 土地利用細分 メッシュの建物用途は, 住宅地・市街地等で建物が 密集しているところと定義される ${ }^{26)}$. 図-7に, 本研 究で推定した丘陵上の造成地と造成宅地地盤図に よって造成地と特定されていた地域を比較する。本 研究の造成地と宅地造成地盤図の造成地は, 2 地域 


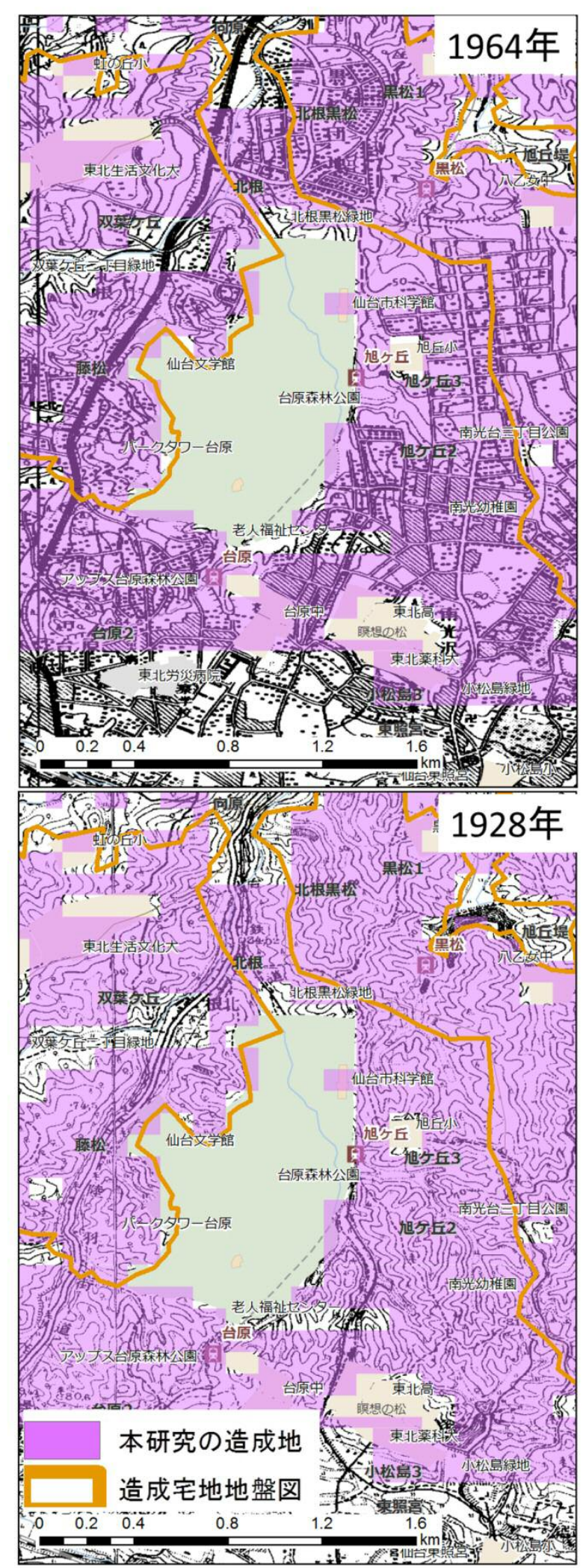

図-8旧版地形図を用いた造成地の抽出結果の検証（仙 台市青葉区旭ヶ丘)

で大きく異なる，まず，青葉区高野原，赤坂は，微地 形区分ではローム台地として分類されるため，丘陵 の造成地を把握することを目的とする本研究の手法 では抽出されていない.
表-2 本研究で用いた地震観測記録

\begin{tabular}{|c|c|c|c|c|}
\hline 観測点 & $\begin{array}{c}\text { 東経 } \\
\left({ }^{\circ}\right)\end{array}$ & $\begin{array}{c}\text { 北緯 } \\
\left({ }^{\circ}\right)\end{array}$ & $\begin{array}{l}\mathrm{PGV} \\
(\mathrm{cm} / \mathrm{s})\end{array}$ & 観測網 \\
\hline 柳生中学校 & 140.872 & 38.189 & 76.2 & \multirow{16}{*}{$\begin{array}{l}\text { Small- } \\
\text { Titan }\end{array}$} \\
\hline 東四郎丸小学校 & 140.923 & 38.194 & 86.0 & \\
\hline 荒浜小学校 & 140.980 & 38.223 & 80.3 & \\
\hline 東長町小学校 & 140.890 & 38.220 & 81.0 & \\
\hline 太白小学校 & 140.818 & 38.231 & 35.1 & \\
\hline 栗生小学校 & 140.786 & 38.267 & 54.3 & \\
\hline 東北工大香澄町 & 140.851 & 38.246 & 70.4 & \\
\hline 東北工大二ツ沢 & 140.870 & 38.234 & 54.0 & \\
\hline 七郷中学校 & 140.946 & 38.237 & 145.4 & \\
\hline 仙台工業高校 & 140.918 & 38.259 & 68.5 & \\
\hline 連坊小路小学校 & 140.887 & 38.252 & 61.6 & \\
\hline 桜丘小学校 & 140.851 & 38.303 & 58.7 & \\
\hline 宮城県立盲学校 & 140.879 & 38.278 & 53.9 & \\
\hline 南光台東小学校 & 140.913 & 38.299 & 77.0 & \\
\hline 岩切中学校 & 140.945 & 38.302 & 106.4 & \\
\hline 七北田中学校 & 140.892 & 38.324 & 84.9 & \\
\hline 古城小学校 & 140.897 & 38.236 & 64.2 & \multirow{12}{*}{ DCRC } \\
\hline 東六鄉小学校 & 140.949 & 38.199 & 77.8 & \\
\hline 第一中学校 & 140.846 & 38.273 & 55.5 & \\
\hline 将監中央小学校 & 140.874 & 38.337 & 64.6 & \\
\hline 松森小学校 & 140.919 & 38.320 & 118.9 & \\
\hline 宮城県立図書館 & 140.839 & 38.346 & 64.4 & \\
\hline 沖野小学校 & 140.914 & 38.226 & 78.9 & \\
\hline 南小泉小学校 & 140.906 & 38.245 & 63.3 & \\
\hline 西多賀中学校 & 140.852 & 38.226 & 53.6 & \\
\hline 富沢中学校 & 140.863 & 38.218 & 58.1 & \\
\hline 東配水管理事務所 & 140.927 & 38.253 & 77.1 & \\
\hline $\begin{array}{l}\text { 長町南コミュニティ } \\
\text { センター }\end{array}$ & 140.881 & 38.224 & 72.7 & \\
\hline K-NET仙台 & 140.929 & 38.266 & 84.8 & K-NET \\
\hline
\end{tabular}

青葉区旭ヶ丘では, 造成宅地地盤図の造成地より もやや広い範囲が抽出される結果となった。この地 域に関して, 図-8のように旧版地形図を用いて抽出 結果の検証を行った。1 1964 年 (昭和 39 年) 測量の地 形図によると，地下鉄台原駅周辺と旭ヶ丘駅の東側 と南側は，すでに宅地用に整地されていることが分 かる。一方, 1928 年 (昭和 3 年) 測量の地形図では, これらの地域に等高線が密に存在することから, 原 地形は起伏が大きい地形であったものと考えられ る。前述のように，造成宅地地盤図は昭和 30,40 年 代の地形図を用いて旧地形の標高が取得されたた め, すでに造成が済んでいた青葉区旭ヶ丘周辺では, 造成地の範囲が実際よりもやや狭くなったものと考 えられる, 本研究の方法は, 詳細な造成宅地地盤図 のように盛土や切土厚さを把握することはできない が, 古い造成地も含めて場所や広さを把握すること ができる。このことから, 盛土造成地の詳細な評価 を行う前のスクリーニングや, 広域を対象とした地 震被害想定などで宅地造成地の影響を考慮する場合 

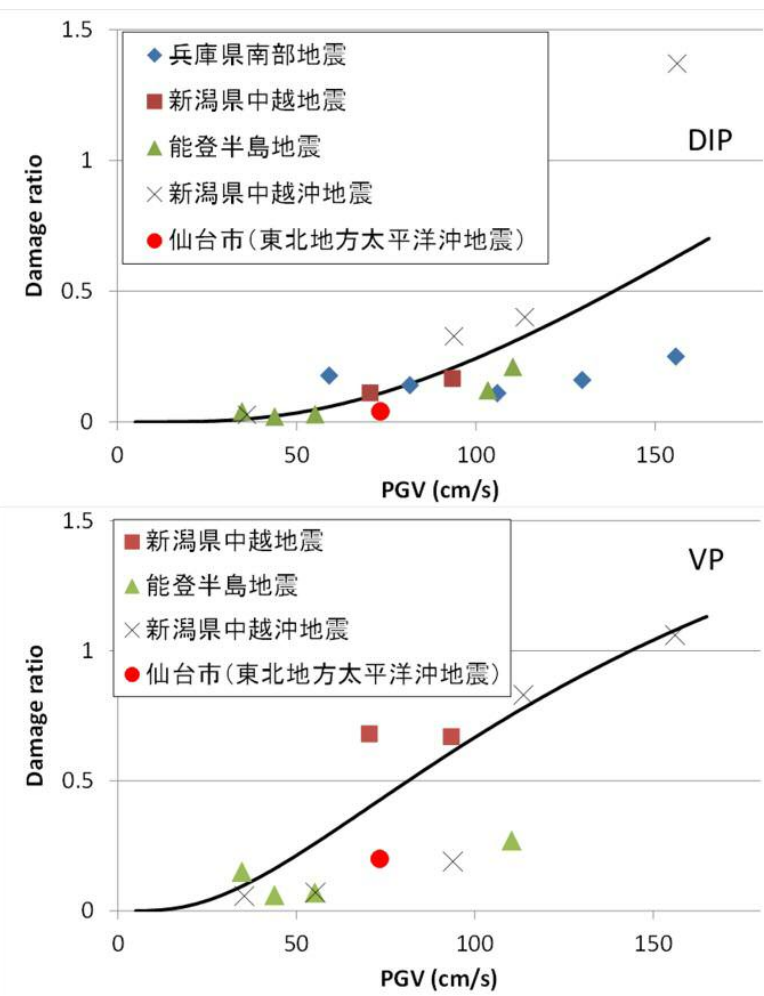

図-9 東北地方太平洋沖地震の仙台市全域における水道 管被害率と既往地震の際の被害率の比較

に有効な手法と考えられる.

本研究で抽出した丘陵の造成地上の導水・送水· 配水管の被害数は 269 件であり, 仙台市全域での被 害 (437 件) の約 6 割を占めている。また造成地上の
土木学会論文集A1 (構造·地震工学), Vol. 70, No. 3, 377-388, 2014.

被害率は 0.23 件/ $\mathrm{km}$ となり, 仙台市全域の被害率 (約 0.1 件 $/ \mathrm{km})^{5)}$ と比べて 2 倍以上高かった.

\section{4. 地震動強さと水道管路被害率の関係}

宮城県仙台市における水道管被害率と地震動強さ の関係を評価するために, 仙台市内の強震記録とし て東北大学災害制御研究センター（DCRC）による観 測記録 ${ }^{28)}$, 東北工業大学の Small-Titan ${ }^{29)}$ および防災 科学技術研究所の $\mathrm{K}-\mathrm{NET}^{30)}$ 仙台 (MYG013) の観測 記録を用いた。地震動指標には式（1）を鑑みて最大 速度 $(\mathrm{PGV})$ を選び, 水平 2 成分の合成值として算出 した（表-2）。仙台市内の平均 PGVは $73.4 \mathrm{~cm} / \mathrm{s}$ で あり, $100 \mathrm{~cm} / \mathrm{s}$ 以上の $\mathrm{PGV}$ を 3 観測点で示した。 丸 山・山崎 ${ }^{10)}$ は, 磯山ら ${ }^{7)}$ がとりまとめた兵庫県南部 地震の際の水道管被害率に, 日本水道協会などが公 開する新潟県中越地震, 能登半島地震, 新潟県中越 沖地震の際の市町村単位の被害率を加えて地震動強 さと被害率の関係を評価している。この結果に，東 北地方太平洋沖地震の際の仙台市全域における被害 率 (DIP：0.04 件/ $\mathrm{km}, \mathrm{VP} ： 0.20$ 件 $/ \mathrm{km})^{5)}$ を加筆す ると図-9のようになる。ここで, 仙台市の地震動強 さは $\mathrm{PGV}$ の平均である $73.4 \mathrm{~cm} / \mathrm{s}$ とし, 丸山・山 崎 $^{10)}$ によるDIP および鋳鉄管（CIP）と VP の標準被 害率曲線 $R(v)$ を併せて示す，鍬田・片桐 4$)$ などに

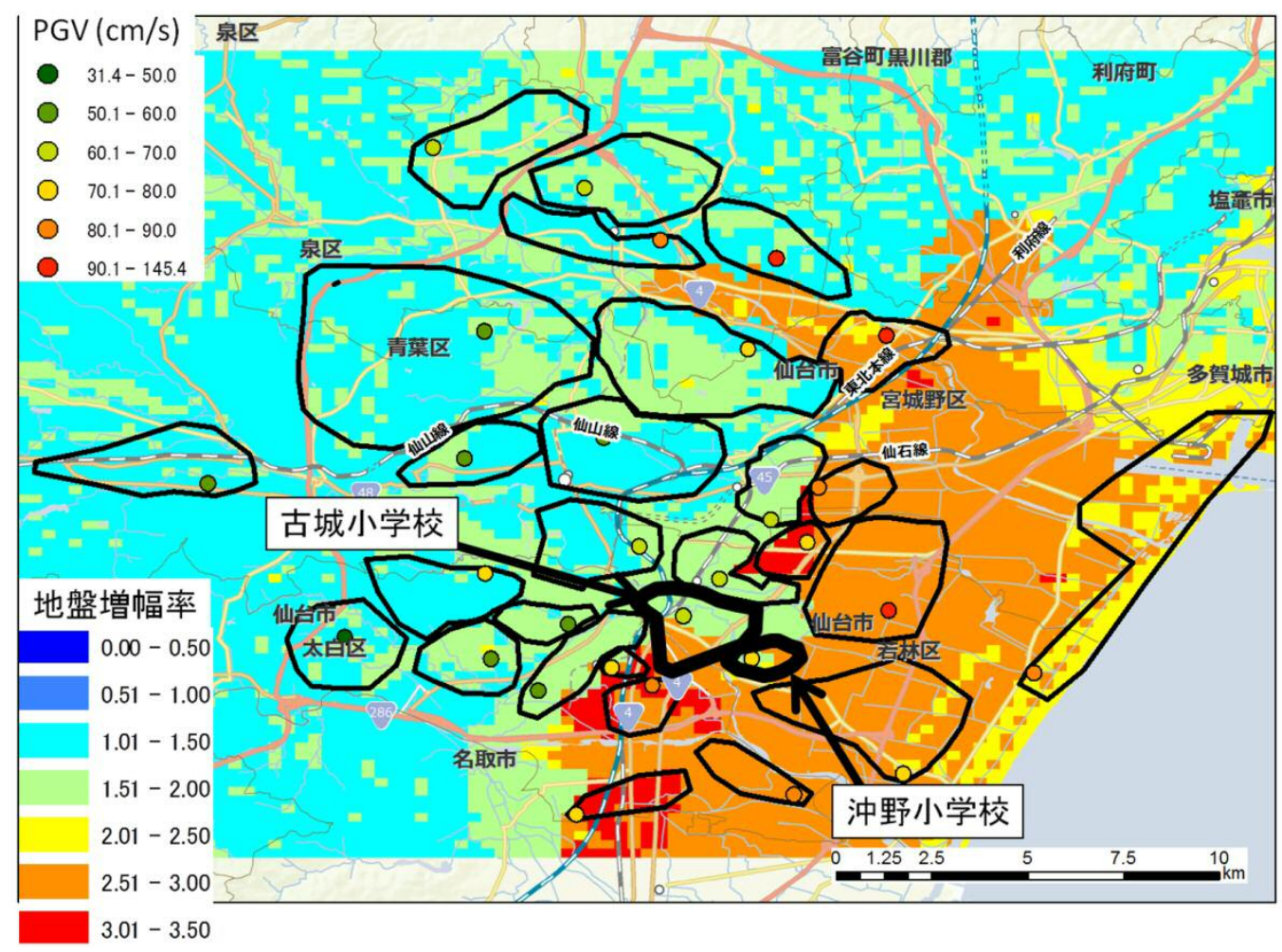

図-10 Vs30 ${ }^{15)}$ を利用して推定した地盤増幅率の分布と本研究で設定した地震観測值の有効範囲 
表-3 PGV と水道管路延長および被害数（管径 100-150 $\mathrm{mm})$

\begin{tabular}{c|r|r|r|r|r|r|r|r|r|}
\hline & & \multicolumn{2}{|c|}{ 造成地 } & \multicolumn{2}{|c|}{$C_{g}=0.8$} & \multicolumn{2}{|c|}{$C_{g}=1.0$} & \multicolumn{2}{|c|}{$C_{g}=2.5$} \\
\hline $\begin{array}{c}\text { PGV } \\
(\mathrm{cm} / \mathrm{s})\end{array}$ & $\begin{array}{c}\text { Mean of } \\
\text { PGV } \\
(\mathrm{cm} / \mathrm{s})\end{array}$ & DIP & VP & DIP & VP & DIP & VP & DIP & VP \\
\hline-60 & 55.6 & 10 & 11 & 5 & 4 & 3 & 3 & 0 & 0 \\
\hline $60-70$ & 64.0 & 57.8 & 63.7 & 97.1 & 46.6 & 26.5 & 21.4 & 0.0 & 0.1 \\
\hline $70-80$ & 76.2 & 20 & 17 & 27.3 & 7 & 0 & 4 & 0 & 0 \\
\hline $80-90$ & 83.2 & 0 & 35.4 & 5.3 & 1.3 & 29.0 & 26.4 & 4.0 & 1.6 \\
\hline $90-100$ & - & - & - & 0 & 0 & 0 & 0 & 0 \\
\hline $100-$ & 135.0 & 23.3 & 16.0 & 2.7 & 12.2 & 9.1 & 23.9 & 8.3 \\
\hline
\end{tabular}

上段 : 被害数, 下段 : 管路延長 $(\mathrm{km})$

表-4 PGV と水道管の被害率（管径 100-150 mm）

\begin{tabular}{c|c|c|c|c|c|c|c|c|c|}
\hline & & \multicolumn{2}{|c|}{ 造成地 } & \multicolumn{2}{c|}{$C_{g}=0.8$} & \multicolumn{2}{c|}{$C_{g}=1.0$} & \multicolumn{2}{|c|}{$C_{g}=2.5$} \\
\hline $\begin{array}{c}\text { PGV } \\
(\mathrm{cm} / \mathrm{s})\end{array}$ & $\begin{array}{c}\text { Mean of } \\
\begin{array}{c}\text { PGV } \\
(\mathrm{cm} / \mathrm{s})\end{array}\end{array}$ & DIP & VP & DIP & VP & DIP & VP & DIP & VP \\
\hline-60 & 55.6 & 0.08 & 0.17 & 0.05 & 0.09 & 0.11 & 0.14 & & \\
\hline $60-70$ & 64.0 & 0.07 & 0.18 & 0.04 & 0.00 & 0.00 & 0.15 & 0.00 & 0.00 \\
\hline $70-80$ & 76.2 & 0.30 & 0.48 & 0.19 & 3.01 & 0.00 & 0.08 & 0.00 & 0.00 \\
\hline $80-90$ & 83.2 & & & 0.00 & 0.00 & 0.00 & 0.33 & 0.08 & 0.00 \\
\hline $90-100$ & - & - & - & - & - & - & - & - & - \\
\hline $100-$ & 135.0 & 0.09 & 1.76 & & & 0.09 & 0.13 & 0.07 & 0.28 \\
\hline
\end{tabular}
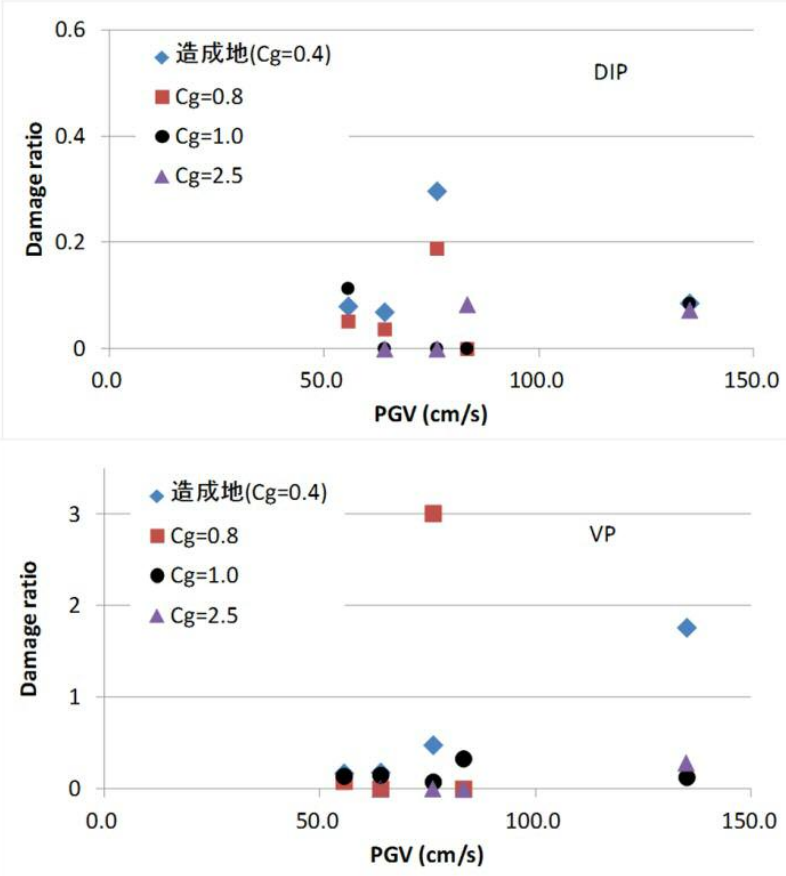

図-11 仙台市における地震動強さと水道管被害率の関係 (管径 100-150 mm)

よって指摘されているように, 過去の地震の際の被 害率と比べると東北地方太平洋沖地震の仙台市での 被害率は地震動強さの割には小さい.

兵庫県南部地震の際の水道管被害率は, 地震動強 さと対応付けるために，地震観測点周辺の $2 \mathrm{~km}$ 四方
土木学会論文集A1 (構造·地震工学), Vol. 70, No. 3, 377-388, 2014.

の範囲について算出されている7)。これは, $2 \mathrm{~km}$ 四 方内の地震動強さのばらつきは小さいものと仮定 し，地震計で観測された值をその範囲の摇れの代表 值として使用しているものと解釈できる，一方，地 盤条件の違いによって狭い範囲でも地震動強さが異 なることがある ${ }^{31), 32)}$ ため, 地盤増幅度を考慮した空 間補間によって地震動強さの分布を推定し, 被害率 を算出することもある ${ }^{33), 34)}$. 本研究では, 深さ $30 \mathrm{~m}$ までの地盤の平均 $\mathrm{S}$ 波速度（Vs30）の分布にもとづ き, 地震観測点（29 地点）とほぼ同程度の地震動強 さと考えられる範囲を選定した。Vs30は, 微地形区 分, 標高, 傾斜, 先第三系・第三系の山地・丘陵から の距離にもとづき推定され ${ }^{35)}$, 地盤増幅率と相関が ある ${ }^{36)}$ ．図-10 は，Vs30の分布 ${ }^{15)} も と に$ 藤本・翠 川の方法 ${ }^{36)}$ で推定した地盤増幅率と本研究で定めた 地震計の影響範囲の関係を示している。本研究のよ うに比較的狭い範囲を検討対象とする場合は, 地盤 増幅率には微地形区分の影響が強く反映されること となる。な技，図中で影響範囲を太線で示している 古城小学校と沖野小学校は, 自然堤防と扇状地の境 界部に位置している。このため, 微地形区分の境界 で地盤増幅率の推定值が急変している。しかし, 両 微地形区分の対応する元々の地盤条件は微地形境界 で急変するものではなく, 境界付近では両微地形区 分の地盤特性（自然堤防では砂地盤，扇状地は砂礫 地盤）の中間的な特性を有していると推定される。 このことから, これらの 2 地点に関しては, あえて 2 つの微地形区分にまたがって地震計の影響範囲を設 定した。

地震観測点周りの範囲ごとに管路延長と被害数を まとめ, さらに PGV の大きさによってその結果を集 約した (表-3)。本章では, 式 (1) の地形補正係数 $C_{g}$ と地震動強さを考慮して比較するため, 管径補正係 数 $C_{d}$ が 1.0 と定められている管径 100-150 $\mathrm{mm}$ の延 長と被害率を対象とした。 $P G V$ は概ね $10 \mathrm{~cm} / \mathrm{s}$ 刻み とし, 被害数揖よび管路延長は式（1）の地形補正係 数 $C_{g}$ ごとに集計した. $C_{g}$ が 0.4 と定義される地形区 分に関しては, 前章で抽出した丘陵の造成地での被 害数と管路延長のみを示している。また，本研究で 使用した地震記録のうち $\mathrm{PGV}$ が 90-100 cm/ $\mathrm{s}$ を示す ものはなかったので, データなしとして扱う。造成 地のうち $\mathrm{PGV}$ が $80-90 \mathrm{~cm} / \mathrm{s}$ の場合と $C_{g}$ が 0.8 とさ れる台地のうち $\mathrm{PGV}$ が $100 \mathrm{~cm} / \mathrm{s}$ 以上の場合, およ び $C_{g}$ が 2.5 とされる主として沿岸部の軟弱地盤のう ち $\mathrm{PGV}$ が $60 \mathrm{~cm} / \mathrm{s}$ 未満の場合の管路延長が $0.1 \mathrm{~km}$ 以下と非常に短いため, これらの被害率は算出しな かった（表-4）。な扮, 平均 PGVは, 管路延長による 重み付き平均值とした。 

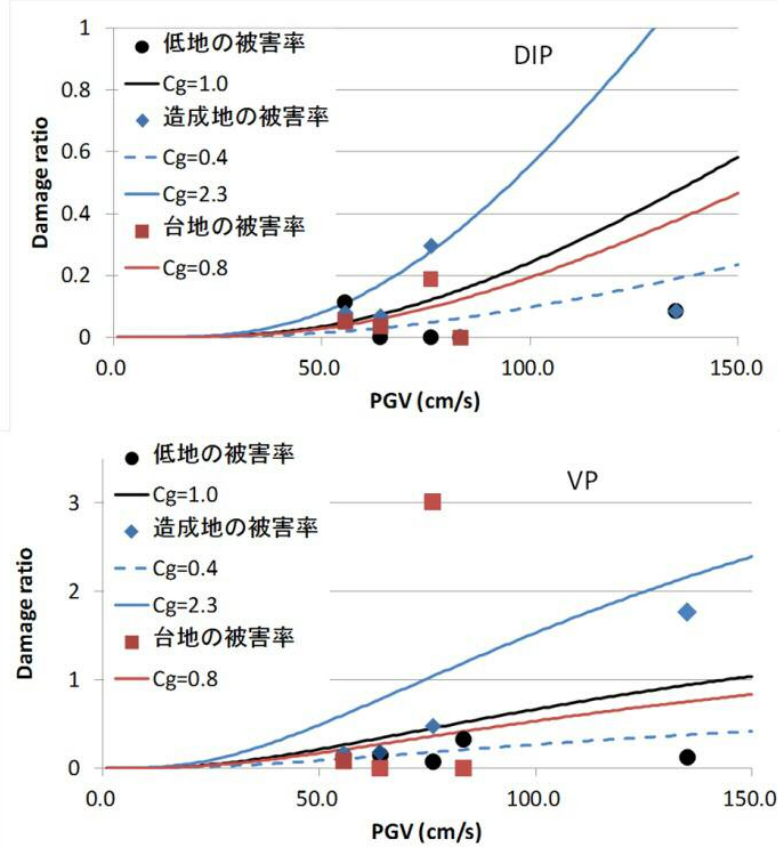

図-12 仙台市内の水道管被害率と地震動強さの関係と造 成地の補正係数の設定例（管径 100-150 mm）

図-11に，宮城県仙台市における地震動強さと水 道管被害率の関係を管種別に示す（管径 100-150 mm のみ). $C_{g}$ が 1.0 とされる低地における DIP の被害 率は概して小さい. $\mathrm{PGVが} \mathrm{60-70} \mathrm{cm/s,} \mathrm{70-80} \mathrm{cm/} \mathrm{s}$ のとき低地では被害がないが, 台地 $\left(C_{g}=0.8\right)$ と造 成地では被害が発生している。とくに造成地の被害 率は高く，補正係数を 0.4 とすることは適当ではな いと考えられる。VPに関しても, 低地よりも造成地 の方が高い被害率を示すことが分かる。このような 丘陵の造成地の被害率が低地の被害率よりも高くな る現象は，これまでの事例でもよく知られているこ とであるが, 現状の被害予測式での扱いとは逆の傾 向を示すものであり, 地震被害予測や水道管路の更 新計画立案の際に充分な配慮が必要なものと考えら れる。

式（1）を用いて仙台市内の水道管被害率と地震動 強さの関係を評価すると図-12のようになる。ここ で，標準被害率 $R(v)$ には丸山・山崎 ${ }^{10)}$ が構築した DIP の式と CIP およびVP の式を用いた（式（3）, 式 (4)).

$$
\begin{aligned}
& R(v)=4.99 \Phi((\ln v-6.04) / 0.864) \\
& R(v)=2.06 \Phi((\ln v-5.00) / 0.860)
\end{aligned}
$$

$\Phi(x)$ は標準正規分布の確率分布関数である。式 $(3)$, （4）は，他の標準被害率7)-9),11）よりも小さい被害率 を示す特徴がある ${ }^{10)}$ 。東北地方太平洋沖地震の際の
土木学会論文集A1 (構造・地震工学), Vol. 70, No. 3, 377-388, 2014.

仙台市の被害率は既往のものと比べて小さいため, 本研究では標準被害率 $R(v)$ には小さめの被害率を 予測する式 (3)，（4）を用いた。低地 $\left(C_{g}=1.0\right)$ で の被害率は, $\mathrm{PGV}$ が $60 \mathrm{~cm} / \mathrm{s}$ 未満のときの DIP の被 害率を除き，全体的に式（3），(4) よりも小さい。台 地での被害率と式 (3)，(4) に地形補正係数 $0.8^{11)}$ を 乗じたものを比較すると, DIP の $\mathrm{PGV}$ が $70 \mathrm{~cm} / \mathrm{s}$ 以 下の被害率については予測結果が実際の被害率とあ る程度一致している。VPは被害率のばらつきが大 きく, 式の当てはまりを評価するのが難しい，丘陵 の造成地での被害率は, 式 (3), (4) に丘陵の地形補 正係数 $0.4^{11)}$ を乗じてしまうと, DIP では PGV が 60 $\mathrm{cm} / \mathrm{s}$ 末満, $70-80 \mathrm{~cm} / \mathrm{s}$ のとき, $\mathrm{VP}$ では 70- $80 \mathrm{~cm} / \mathrm{s}$, $100 \mathrm{~cm} / \mathrm{s}$ 以上のときに被害率が高くなる現象を説明 できず，全体的に過小評価となる，3章で述べたよ うに, 本研究で推定した造成地の被害率は, 仙台市 全域の被害率の約 2.3 倍を示していたため, 暫定的 に2.3 造成地の地形補正係数 $C_{g}$ とみなして式 (3), （4）に乗じたところ，DIP については PGVが 60 $\mathrm{cm} / \mathrm{s}$ 未満, $80-90 \mathrm{~cm} / \mathrm{s}$ のときの被害率と調和的な傾 向を示すようになったＶVPに関しては，本研究で暫 定的に用いた補正係数の值はやや大きいように思わ れるが, 造成地で被害率が大きくなる現象は反映さ れるようになる。

図-11, 図-12 によると, $100 \mathrm{~cm} / \mathrm{s}$ 以上の $\mathrm{PGV}$ を記 録した $3 つ の$ 地震観測点周りの水道管路被害率は, 造成地でのVPの被害率を除き, 地震動強さから推 定される平均的な傾向よりも低かった，永田らも同 様な結果を示しており, これらの地域の管路の耐震 化率が高かったことを理由として挙げている ${ }^{6)}$. 都 市ガスの低圧本支管の被害分析 ${ }^{2}$ でも，この地域の 本支管の耐震化率が高く被害率が低い。本研究で被 害率を算出する際には耐震管を含まない管路延長で 被害数を除しているが, とくにDIPの被害率は低く, 造成地で被害率が高くなる状況もあまり顕著ではな い. 分析対象地域内に扔ける地震動が非常に強い領 域の面積が小さいため, 管路延長が短くなり, 被害 率にばらつきが生じやすいのは事実である（例えば, 図-9）が，ある地域で管路の耐震化を進めると非耐 震管を含めたネットワーク全体の堅牢性が高まる可 能性もあり, 今後の検討課題の一つと考えられる.

このように, 東北地方太平洋沖地震の宮城県仙台 市では, 過去の被害デー夕をもとに構築された被害 予測式と比べてとくに丘陵の造成地で高い被害率を 示した，仙台市の造成地では，谷埋め盛土，腹付け 盛土の地滑り, 斜面の崩壊などの地盤変動が多数報 告されている20),37).1978 年宮城県沖地震の際にも 仙台市北部と南西部の宅地造成地盤で地盤変動に伴 
う家屋被害が多数発生し ${ }^{38)}$ ，これらの宅地造成地盤 で水道管被害も集中した ${ }^{17)}$ が，これと同様の被害が 再び起こったものと考えられる。また，仙台市に限 らず東北地方太平洋沖地震の際には造成宅地で滑動 崩落等が多数発生したため, 国土交通省が造成宅地 滑動崩落緊急対策事業 ${ }^{39)}$ を設けるなど危険性が改め て認識された，丘陵は良質な地盤であるため，現状 の水道管被害予測式では地形補正係数が 0.4 と設定 されているものと思われる。しかしながら，丘陵の 造成宅地では盛土の地滑りなどの地盤変動に伴って 水道管被害が集中することが懸念されることから, 予測手法の改良が必要である。

\section{5. 結論}

本研究では, 東北地方太平洋沖地震の際の宮城県 仙台市に扮ける上水道管路データと導水・送水・配 水管の被害デー夕を用いて, 地震時の水道管被害予 測手法の検証を行った。仙台市では, 437 件の導水・ 送水・配水管被害が発生し，そのうち約 $70 \%$ の 297 件がVP，約 $25 \%$ の 117 件が DIPであった。

仙台市全域の被害率を微地形区分ごとに評価を 行った。管路被害予測式の地形補正係数 $C_{g}$ は, 微地 形区分に対応付けて設定されている. 補正係数が 1.0 と定義される低地 (谷底低地, 扇状地, 後背湿地, 三角州・海岸低地）の被害率を基準とすると, 台地 (砂礫質台地, ローム台地) の VP の被害率は約 0.7 倍となり補正係数の設定值（0.8）とほぼ一致した。 DIP は, 台地で低地よりも約 1.5 倍高い被害率を示 した。補正係数が 2.5 と定義される自然堤防, 旧河 道, 砂州・砂礫洲などの被害率は小さかったが, 津波 による被害が甚大な地域の被害状況が充分に精査さ れていないことが影響している可能性もあるため, 詳細な議論は難しい。

地形補正係数 $C_{g}$ が 0.4 である山地, 山麓地, 丘陵 などに関しては， $C_{g}$ が 1.0 の低地の被害率と比べて DIP が 3 倍以上, VP が 2 倍以上高い被害率を示し, 地形補正係数の設定值との乘離が最も大きかった. この結果をふまえて, 本研究では, 国土数值情報の 土地利用細分メッシュと微地形区分を組み合わせて 丘陵の造成地を推定し, さらに地震動強さの影響も 考慮した検討を行い, 水道管被害予測式に丘陵の造 成地の地形補正係数を新たに導入する必要性を指摘 した。

磯山ら ${ }^{7)}$ が兵庫県南部地震の被害デー夕をもとに 提案した水道管被害予測式では, 山地の地形補正係 数 0.4 に対して改変山地が 1.1 , 谷. 旧水部が 3.2 と
土木学会論文集A1 (構造·地震工学), Vol. 70, No. 3, 377-388, 2014.

提案されており，人工改変地が考慮されている。 し かし, 被害予測式を利用する地震被害想定や管路更 新計画の策定には, 日本全国を均質に網羅している 微地形区分を地盤条件の評価に用いることが多い. そのため, 造成地の被害が多いのは認識されていた ものの地形補正係数が微地形区分ごとに設定される ようになってしまい, 改変地の影響が考慮されなく なったものと考えられる. 本研究では, 丘陵の造成 地を抽出する手法として土地利用細分メッシュと微 地形区分を用いる方法を提案した。 どちらも全国に ついて整備された公開データであるので, 丘陵の造 成地を抽出するのに汎用性が高く, 改変地の場所を 特定することができるようになる。このため，丘陵 の造成地に関して新たな補正係数を導入すれば, 強 震時に発生する地盤変動に伴い水道管被害が集中す ることを説明できるように手法が改良できるものと 考えられる. 本研究では, 仙台市の被害率の分析結 果から補正係数 2.3 を暫定的に用いたが, 他地域の 事例も併せて分析したうえで設定すべきものと思わ れる。なお, その場合には, 低地での液状化が管路 被害に与える影響40)-42)を適切に分離したうえで検 討を行う必要がある。

謝辞：本研究では, 仙台市水道局から借用した 2011 年の配水管路データおよび東北地方太平洋沖地震に おける被害デー夕を使用しました。また，独立行政 法人防災科学技術研究所の K-NET, KiK-net の強震 観測記録, 東北工業大学・リアルタイム強震観測セ ンターの Small-Titan 強震観測記録を使用しました。 関係者各位に深甚なる感謝の意を表します。

\section{参考文献}

1) Nojima, N. : Restorations and system interactions of lifelines in the Great East Japan Earthquake disaster, 2011, Proceedings of the International Symposium on Engineering Lessons Learned from the 2011 Great East Japan Earthquake, pp. 1526-1531, 2012.

2）総合資源エネルギー調査会都市熱エネルギー部会 ガ ス安全小委員会 災害対策ワーキンググループ：東日 本大震災を踏まえた都市ガス供給の災害対策検討報 告書, 2012 .

3）厚生労働省健康局水道課, 日本水道協会: 平成 23 年 （2011 年）東日本大震災水道施設被害等現地調査団報 告書, 2011 .

4）鍬田泰子, 片桐信 : 第 10 章 水道施設の被害, 土木学 会東日本大震災被害調査団緊急地震被害調査報告書, 2011.

5）仙台市水道局：東日本大震災 仙台市水道復旧の記 
録, 2012

6）永田茂, 西野雅夫，鈴木清一：東日本大震災における 上水道管路施設の被害分析, 土木学会第 67 回年次学 術講演会講演概要集, pp. 415-416, 2012.

7）磯山龍二, 石田栄介, 湯根清二, 白水暢：水道管路の 地震被害予測に関する研究, 水道協会雑誌, 第 761 号, pp. 25-40, 1998.

8）国土庁防災局震災対策課：平成 8 年度南関東地域直下 の地震被害想定手法検討調査, 1997.

9）高田至郎, 藤原正弘, 宮島昌克, 鈴木康博, 依田幹雄, 戸島敏雄：直下型地震災害特性に基づく管路被害予測 手法の研究, 水道協会雑誌, Vol. 70, No. 3, pp. 21-37, 2001.

10）丸山喜久, 山崎文雄：近年の地震被害デー夕を加味し たマクロな配水管被害予測式の改良, 土木学会地震工 学論文集, Vol. 30, pp. 565-574, 2009.

11）水道技術研究センター：地震による管路被害予測の確 立に向けた研究報告書【概要版】, 2013.

12）仙台市水道局：平成 23 年度版環境報告書, 2011.

13）日本水道協会：平成 23 年（2011 年）東日本大震災に おける管本体と管路付属設備の被害調查報告書, 2012.

14）日本水道協会：水道施設耐震工法指針・解説，2010.

15）若松加寿江，松岡昌志：全国統一基準による地形・地 盤分類 $250 \mathrm{~m}$ メッシュマップの構築とその利用，日本 地震工学会誌, No. 18, pp. 35-38, 2013.

16）水道技術研究センター：地震による水道管路被害予測 の手引き， 2011 .

17）片山恒雄，増井由春，磯山龍二，甚内郁郎：1978 年宮 城県沖地震による都市供給施設の被害と復旧, 生産研 究, Vol. 31, No. 4, pp. 213-219, 1979.

18）復建技術コンサルタント：造成宅地地盤図に関する研 究のページ, http://www.fgc.jp/solution/technical/kouzou 01/index.html（2014 年 1 月 26 日閲覧）.

19）風間基樹：2011 年東北地方太平洋沖地震による地盤 災害と復興への地盤工学的課題, 東日本大震災に関す る技術講演会論文集，全国地質調査業調査協会連合 会, 東北地質調査業協会, pp. 41-66, 2012.

20）若松加寿江, 吉田望, 清田隆: 第 6 章 造成地の被害, 土木学会東日本大震災被害調査団緊急地震被害調査 報告書, 2011 .

21）佐藤真吾, 栗谷将晴, 南陽介：東北地方太平洋沖地震 における谷埋め盛土造成宅地の被害と復旧課題，第 47 回地盤工学研究発表会, pp. 1477-1478, 2012.

22）国土交通省国土地理院：人工改変地形デー夕抽出のた めの手順書， 2010.

23）栗谷将晴，佐藤真吾，小倉薰，向山雅史：地震防災の ための仙台地区の造成宅地地盤図作成，第 40 回地盤
土木学会論文集A1 (構造・地震工学), Vol. 70, No. 3, 377-388, 2014.

工学研究発表会, pp. 1893-1894, 2004.

24）首都直下地震モデル検討会 : 首都直下の $\mathrm{M} 7$ クラスの 地震及び相模トラフ沿いの M8 クラスの地震等の震源 断層モデルと震度分布・津波高等に関する報告書, 2013.

25）南海トラフの巨大地震モデル検討会 : 南海トラフの巨 大地震による震度分布・津波高について（第一次報 告), 2012.

26）国土交通省国土政策局国土情報課：国土数值情報 ダ ウンロードサービス, http://nlftp.mlit.go.jp/ksj/（2014 年 1 月 26 日閲覧).

27）若松加寿江，松岡昌志，久保純子，長谷川浩一，杉浦 正美：日本全国地形・地盤分類メッシュマップの構築, 土木学会論文集, No. 759/ I-67, pp. 213-232, 2004.

28）大野晋, 三屋栄太, 源栄正人：2011 年東北地方太平洋 沖地震に扔ける仙台市域の地盤震動特性, 日本地震工 学会論文集, Vol. 12, No. 4, pp. 339-353, 2012.

29）神山眞, 松川忠司, 穴澤正宏 : 2011 年東北地方太平洋 沖地震における東北工業大学アレー強震観測システ ム Small-Titanによる強震記録について (速報), 2011.

30）防災科学技術研究所 : 強震観測網 (K-NET, KiK-net), http://www.kyoshin.bosai.go.jp/kyoshin/（2014 年 1 月 26 日閲覧)。

31）時松孝次, 新井洋, 関口徹: 2004 年新潟県中越地震時 に表層地盤の非線形震動増幅特性が小千谷の木造住 宅被害に与えた影響, 日本建築学会構造系論文集, No. 620, pp. 35-42, 2007

32) Hata, Y., Nozu, A. and Ichii, K. : A practical method to estimate strong ground motions after an earthquake, based on site amplification and phase characteristics, Bulletin of the Seismological Society of America, Vol. 101, No. 2, pp. 688-700, 2011.

33）酒井久和, 長谷川浩一, Nelson Pulido：広域水道管路に 対する震害予測手法の提案 - 2004 年新潟県中越地 震への適用一, 土木学会論文集 A, Vol. 66, No. 3, pp. 561-567, 2010.

34）庄司学, 櫻井俊彰：2008 年岩手・宮城内陸地震におけ る斜面に関わる道路構造物の損傷モード分析とそれ を踏まえた被害関数の構築, 日本地震工学会論文集, Vol. 11, No. 5, pp. 94-106, 2011.

35）松岡昌志，若松加寿江，藤本一雄，翠川三郎：日本全 国地形・地盤分類メッシュマップを利用した地盤の平 均 $\mathrm{S}$ 波速度分布の推定, 土木学会論文集, No. 794/ I-72, pp. 239-251, 2005.

36）藤本一雄，翠川三郎：近接観測点ペアの強震記録に基 づく地盤増幅度と地盤の平均 $\mathrm{S}$ 波速度の関係, 日本地 震工学会論文集, Vol. 6, No. 1, pp. 11-22, 2006.

37 ）釜井俊孝：2011 年東北地方太平洋沖地震によって発生 
土木学会論文集A1 (構造・地震工学), Vol. 70, No. 3, 377-388, 2014.

した造成地盤の地すべり (第2 報), http://www.dpri.ky oto-u.ac.jp/web_j/saigai/tohoku2011/land_20110701.pdf (2014 年 1 月 26 日閲覧).

38）沖村孝, 鍋島康之, 岡田肇, 野並賢: 東北地方太平洋 沖地震による仙台市内及び周辺の宅地被害調查報告, https://www.jiban.or.jp/file/file/saigai_okimura_nabeshima _okada_nonami_0430_mini.pdf（2014 年 1 月 26 日閲 覧).

39）国土交通省：造成宅地滑動崩落緊急対策事業の創設に ついて, http://www.mlit.go.jp/toshi/toshi_tk1_000003.ht $\mathrm{ml}$ (2014 年 1 月 26 日閲覧).

40）星野愛子, 宮島昌克：近年の地震被害を考慮した上水
道管路の被害予測式の改良に関する研究，第 5 回相互 連関を考慮したライフライン減災対策に関するシン ポジウム講演集, 土木学会, pp. 20-26, 2013.

41）鍬田泰子, 池尻大介：管路被害集中地域の地形や噴砂 痕と被害箇所の関係, 土木学会第 68 回年次学術講演 会講演概要集, pp. 281-282, 2013.

42）築地拓哉, 寺嶋黎, 庄司学, 永田茂: 東北地方太平洋 沖地震で被災した上水道配水管の被害分析及びそれ を踏まえた被害率曲線の構築, 土木学会第 68 回年次 学術講演会講演概要集, pp. 283-284, 2013.

\section{INVESTIGATION OF DAMAGE RATIO OF WATER DISTRIBUTION PIPELINE IN SENDAI CITY AFTER THE 2011 OFF THE PACIFIC COAST OF TOHOKU EARTHQUAKE}

\section{Yoshihisa MARUYAMA, Tomohiro ITO, Kazue WAKAMATSU and Shigeru NAGATA}

The 2011 off the Pacific coast of Tohoku Earthquake with the moment magnitude of 9.0 caused severe damage to lifeline systems. In Sendai City, Miyagi Prefecture, where is the most populated city in Tohoku district, the suspension of water supply was occurred at approximately 230, 000 family units. This study investigates the relationship between the damage ratio of water distribution pipeline and ground motion intensity in Sendai City during the earthquake. The damage ratios in the developed hilly areas are compared with those in lowland considering the ground motion intensity. Based on the results, the use of correction coefficient for the developed hilly area is proposed to predict the number of pipe breaks of water distribution pipeline. 